\title{
Sustained enhancement of photosynthesis in mature deciduous forest trees after 8 years of free air $\mathrm{CO}_{2}$ enrichment
}

\author{
Martin Karl-Friedrich Bader • Rolf Siegwolf • \\ Christian Körner
}

Received: 12 June 2010/ Accepted: 22 July 2010/Published online: 11 August 2010

(C) Springer-Verlag 2010

\begin{abstract}
Carbon uptake by forests constitutes half of the planet's terrestrial net primary production; therefore, photosynthetic responses of trees to rising atmospheric $\mathrm{CO}_{2}$ are critical to understanding the future global carbon cycle. At the Swiss Canopy Crane, we investigated gas exchange characteristics and leaf traits in five deciduous tree species during their eighth growing season under free air carbon dioxide enrichment in a 35-m tall, ca. 100-year-old mixed forest. Net photosynthesis of upper-canopy foliage was $48 \%$ (July) and $42 \%$ (September) higher in $\mathrm{CO}_{2}$-enriched trees and showed no sign of down-regulation. Elevated $\mathrm{CO}_{2}$ had no effect on carboxylation efficiency $\left(V_{\mathrm{cmax}}\right)$ or maximal electron transport $\left(J_{\max }\right)$ driving ribulose-1, 5-bisphosphate (RuBP) regeneration. $\mathrm{CO}_{2}$ enrichment improved nitrogen use efficiency, but did not affect leaf nitrogen $(\mathrm{N})$ concentration, leaf thickness or specific leaf area except for one species. Non-structural carbohydrates accumulated more strongly in leaves grown under elevated $\mathrm{CO}_{2}$ (largely driven by Quercus). Because leaf area index did not change, the $\mathrm{CO}_{2}$-driven stimulation of photosynthesis in these trees may persist in the upper canopy under future atmospheric $\mathrm{CO}_{2}$ concentrations without reductions in photosynthetic capacity. However, given the lack of growth stimulation, the fate of the additionally assimilated carbon remains uncertain.
\end{abstract}

M. K.-F. Bader $(\varangle) \cdot$ C. Körner

Institute of Botany, University of Basel, Schönbeinstrasse 6, 4056 Basel, Switzerland

e-mail: Martin.Bader@unibas.ch

R. Siegwolf

Paul Scherrer Institute, 5323 Villigen PSI, Switzerland
Keywords Elevated $\mathrm{CO}_{2} \cdot$ Global change .

Photosynthetic acclimation - Swiss Canopy Crane

\begin{tabular}{|c|c|}
\hline \multicolumn{2}{|c|}{ Abbreviations } \\
\hline$A_{\text {growth }}$ & $\begin{array}{l}\text { Light-saturated net photosynthesis measured at } \\
\text { growth } \mathrm{CO}_{2} \text { concentration (ambient } \mathrm{CO}_{2}: \\
\left.A_{\text {growth }}^{\mathrm{a}} \text {; elevated } \mathrm{CO}_{2}: A_{\text {growth }}^{\mathrm{e}}\right)\end{array}$ \\
\hline$A_{550}$ & $\begin{array}{l}\text { Light-saturated net photosynthesis measured at } \\
550 \mathrm{ppm} \text { leaf chamber } \mathrm{CO}_{2} \text { concentration }\end{array}$ \\
\hline$A_{380}$ & $\begin{array}{l}\text { Light-saturated net photosynthesis measured at } \\
380 \mathrm{ppm} \text { leaf chamber } \mathrm{CO}_{2} \text { concentration }\end{array}$ \\
\hline $\mathrm{C}$ & Carbon \\
\hline$E$ & $A_{\text {growth }}^{\mathrm{e}} / A_{\text {growth }}^{\mathrm{a}}$ \\
\hline$E^{\prime}$ & $A_{550} / A_{380}$ \\
\hline FACE & Free air carbon dioxide enrichment \\
\hline$J_{\max }$ & $\begin{array}{l}\text { Maximal photosynthetic electron transport rate } \\
\text { (a proxy for ribulose-1,5-bisphosphate } \\
\text { regeneration) }\end{array}$ \\
\hline LAI & Leaf area index \\
\hline $\mathrm{N}$ & Nitrogen \\
\hline PPFD & Photosynthetic photon flux density \\
\hline SLA & Specific leaf area \\
\hline NSC & Non-structural carbohydrates \\
\hline SCC & Swiss canopy crane \\
\hline SE & Standard error of the mean \\
\hline$V_{\text {cmax }}$ & Maximal carboxylation rate of Rubisco \\
\hline ALVPD & Air-to-leaf vapour pressure deficit \\
\hline
\end{tabular}

\section{Abbreviations} growth $\mathrm{CO}_{2}$ concentration (ambient $\mathrm{CO}_{2}$ : growth; elevated $\mathrm{CO}_{2}: A_{\text {growth }}^{\mathrm{e}}$ 550 ppm leaf chamber $\mathrm{CO}_{2}$ concentration $380 \mathrm{ppm}$ leaf chamber $\mathrm{CO}_{2}$ concentration Carbon$$
A_{\text {growth }}^{\mathrm{e}} / A_{\text {growth }}^{\mathrm{a}}
$$

FACE Free air carbon dioxide enrichment

$J_{\max } \quad$ Maximal photosynthetic electron transport rate (a proxy for ribulose-1,5-bisphosphate$$
\text { Leaf area index }
$$

N Nitrogen

PPFD Photosynthetic photon flux density

Specific leaf area

Non-structural carbohydrates

SCC Swiss canopy crane

$V_{\text {cmax }} \quad$ Maximal carboxylation rate of Rubisco

ALVPD Air-to-leaf vapour pressure deficit

\section{Introduction}

Every year, the burning of fossil fuels and dramatic changes in land use feed vast amounts of $\mathrm{CO}_{2}$ to the 
atmosphere (Le Quéré et al. 2009). The uptake of $\mathrm{CO}_{2}$ from the atmosphere through photosynthesis and its recycling through respiratory processes represent the largest fluxes in the global carbon (C) cycle (Schimel 1995; Sabine et al. 2004). If the $\mathrm{C}$ assimilated by plants is not completely recycled and some remains stored in the biosphere for prolonged periods, this could mitigate atmospheric $\mathrm{CO}_{2}$ enrichment. The knowledge of the long-term response of photosynthesis to elevated atmospheric $\mathrm{CO}_{2}$ is key to understanding such future ecosystem responses. Under the current atmospheric $\mathrm{CO}_{2}$ concentration that exceeds the pre-industrial level by nearly $40 \%$, photosynthesis in $\mathrm{C}_{3}$-plants is still $\mathrm{CO}_{2}$ limited (Farquhar et al. 1980; Tans 2008). Hence, photosynthetic rates increase in response to elevated $\mathrm{CO}_{2}$, because the increased substrate availability stimulates Rubisco (ribulose-1,5-bisphosphate carboxylase/ oxygenase) carboxylation whilst competitively inhibiting the oxygenation process (Drake et al. 1997; Ainsworth and Rogers 2007). In trees that harbour $~ 90 \%$ of the terrestrial biomass carbon (Roy et al. 2001) and account for $50 \%$ of the terrestrial net primary production (Bonan 2008), elevated $\mathrm{CO}_{2}$ has been reported to increase leaf photosynthesis by $30-60 \%$, regardless of tree age (Gunderson and Wullschleger 1994; Curtis and Wang 1998; Saxe et al. 1998; Medlyn et al. 1999; Norby et al. 1999; Nowak et al. 2004; Ainsworth and Long 2005). The magnitude of this stimulation is species dependent and modulated by environmental factors such as light, temperature, soil water and nutrient supply (Curtis and Wang 1998; Nowak et al. 2004).

Sustained photosynthetic stimulation is one of the prerequisites for growth stimulation under elevated $\mathrm{CO}_{2}$. However, there is no direct translation of $\mathrm{CO}_{2}$ uptake per unit leaf area into plant growth (Körner 2006). In fact, long-term exposure to elevated $\mathrm{CO}_{2}$ may affect morphological, biochemical and physiological plant properties that feed back to both photosynthesis and net carbon incorporation into the plant body (Gunderson and Wullschleger 1994; Egli et al. 2001). Photosynthetic acclimation to elevated $\mathrm{CO}_{2}$ commonly occurs at the biochemical level through decreases in Rubisco carboxylation $\left(V_{\text {cmax }}\right)$ resulting from reductions in Rubisco concentration and, less importantly, through declines in the maximal electron transport rate $\left(J_{\max }\right.$; Drake et al. 1997; Moore et al. 1999; Stitt and Krapp 1999; Ellsworth et al. 2004; Ainsworth and Rogers 2007). Imbalances in sink-source relations due to reduced or insufficient sink capacity often result from nutrient limitations (e.g. growth at low fertility sites or progressive nitrogen limitation) and lead to accumulation of photosynthates in leaves (Körner and Miglietta 1994). This sugar signal triggers a response mechanism that targets the small subunit of Rubisco and eventually leads to selective down-regulation of Rubisco (Rogers and
Ellsworth 2002; Long et al. 2004; Ainsworth and Rogers 2007). Non-selective down-regulation on the other hand emerges from a loss of total leaf $\mathrm{N}$ or the dilution of leaf $\mathrm{N}$ by non-structural carbohydrates (NSC), which indirectly affect Rubisco concentration (Ellsworth et al. 2004). Early observations of photosynthetic down-regulation could be largely attributed to experimental constraints such as pot size (restricted rooting volume; Drake et al. 1997). However, also in field experiments, where the spatial constraints on the root system had been overcome, down-regulation of photosynthesis occurred in $\mathrm{CO}_{2}$-enriched trees, resulting mainly from reduced carboxylation capacity due to leaf $\mathrm{N}$ dilution (on mass and area basis) by NSC accumulation, i.e. from a non-selective, indirect effect on Rubisco (Medlyn et al. 1999; Ellsworth et al. 2004). When photosynthetic down-regulation occurs, the stimulative effect of elevated $\mathrm{CO}_{2}$ is diminished but not completely eliminated, and photosynthesis is still enhanced under elevated $\mathrm{CO}_{2}$ even after several years of enrichment (Saxe et al. 1998; Crous et al. 2008). In a meta-analysis comprising $\mathrm{CO}_{2}$ fertilisation experiments other than free air carbon dioxide enrichment (FACE), photosynthesis of (mostly young) European forest trees declined over time by $10-20 \%$ under elevated $\mathrm{CO}_{2}$, but was still stimulated by $51 \%$ relative to control trees (350 vs. 700 ppm CO $\mathrm{CO}_{2}$; Medlyn et al. 1999). In FACE experiments, down-regulation of photosynthetic capacity was observed in the aggrading Aspen-FACE stands; however, this was a transitory effect that disappeared after steady-state LAI had been reached (Ellsworth et al. 2004; Uddling et al. 2009). A strong sugar-mediated, selective down-regulation of Rubisco occurred in old needles of mature Pinus taeda growing in an N-limited steady-state system at the Duke-FACE facility (Rogers and Ellsworth 2002; Crous et al. 2008).

Despite the bulk of literature on the effects of elevated $\mathrm{CO}_{2}$ on photosynthesis in trees, very few studies have addressed the responses of mature dominant trees that have reached steady-state canopy development (constant leaf area index). The FACE experiment at the Swiss Canopy Crane (SCC) is the only study worldwide where several species of hardwood trees growing in a near-natural, mature mixed forest were exposed to elevated atmospheric $\mathrm{CO}_{2}$. We evaluated the long-term $\mathrm{CO}_{2}$ response of photosynthesis and associated leaf traits in five tree species during the 8th year of canopy $\mathrm{CO}_{2}$ enrichment. Our objective was to assess the magnitude of photosynthetic enhancement and potential down-regulation under elevated $\mathrm{CO}_{2}$. Gas exchange, biochemical and morphological leaf parameters were measured in sunlit foliage during the mid and late growing season to account for seasonal sinksource dynamics. Given the lack of persistent growth stimulation above and below ground in the $\mathrm{CO}_{2}$-enriched trees of this stand (Körner et al. 2005; Asshoff et al. 2006; 
Bader et al. 2009), we anticipated that reduced sink capacity would feed back to photosynthesis, thereby partially offsetting the $\mathrm{CO}_{2}$-induced stimulation of leaf-level $\mathrm{C}$ uptake. Such a decline in photosynthetic enhancement would involve: (1) a reduction of the maximal rate of leaf photosynthesis; (2) a decline in $V_{\text {cmax }}$ and/or $J_{\max }$; (3) increased foliar non-structural carbohydrate (NSC) concentration; (4) diminished leaf nitrogen concentration (mass based); and (5) reduced specific leaf area (SLA).

\section{Materials and methods}

\section{Study site}

The Swiss Canopy Crane (SCC) facility is located in a species-rich forest $15 \mathrm{~km}$ south of Basel, Switzerland $\left(47^{\circ} 28^{\prime} \mathrm{N}, 7^{\circ} 30^{\prime} \mathrm{E}, 550 \mathrm{~m}\right.$ a.s.l.). The ca. 100 -year-old stand grows on a gentle NNW-exposed slope and reaches canopy heights from 30 to $35 \mathrm{~m}$. The leaf area index (LAI) is around 5 , tree density is 415 trees $\mathrm{ha}^{-1}$ (breast height diameter $\geq 0.1 \mathrm{~m}$ ) and stem basal area amounts to $46 \mathrm{~m}^{2} \mathrm{ha}^{-1}$. The forest is dominated by Fagus sylvatica L., Quercus petraea (Matt.) Liebl. and Carpinus betulus L., accompanied by less abundant tree species such as Tilia platyphyllos Scop., Acer campestre L., Prunus avium L. and four species of conifers (Picea abies (L.) Karst., Larix decidua Mill., Pinus sylvestris L., Abies alba Mill.). The soil type is a Rendzic Leptosol (WRB) (Rendzina, FAO; Lithic Rendoll, USDA) with an accessible profile depth of maximal $25 \mathrm{~cm}$ followed by rocky subsoil merging into the calcareous bedrock at depths of $40-90 \mathrm{~cm}$. The soil texture was classified as loamy clay with a $\mathrm{pH}$ of 5.8 in the top $10 \mathrm{~cm}$ of the profile.

The climate in this temperate region is distinguished by mild winters and moderately warm summers with mean air temperatures in January and July of 2 and $19^{\circ} \mathrm{C}$, respectively. Long-term mean annual precipitation in the study region is $990 \mathrm{~mm}$. Approximately two-thirds of the yearly precipitation falls during the 6-month growing season (Pepin and Körner 2002).

Free air $\mathrm{CO}_{2}$-enrichment system

Future $\mathrm{CO}_{2}$ levels in the tree canopies were established by applying a novel free air $\mathrm{CO}_{2}$-enrichment (FACE) technique called web-FACE (Pepin and Körner 2002). Briefly, pure $\mathrm{CO}_{2}$ was pulse released through a fine web of perforated tubes plaited into tree crowns with the help of a construction crane. Canopy $\mathrm{CO}_{2}$ supply was governed via computer-controlled magnetic valves to maintain the target $\mathrm{CO}_{2}$ concentration of $550 \mathrm{ppm}$ as accurately as possible. $\mathrm{CO}_{2}$ concentration in the canopy served as the main control signal and was monitored by an air sampling system consisting of multiple suction heads per tree feeding canopy air through sampling lines into infrared gas analysers. $\mathrm{CO}_{2}$ release was confined to daylight hours (photosynthetic photon flux density, PPFD $>100 \mu \mathrm{mol} \mathrm{m} \mathrm{m}^{-2} \mathrm{~s}^{-1}$ ) of the growing season and was disengaged from the time of leaf shedding to bud break (end of October to mid-April). Twelve deciduous trees growing in the $60 \mathrm{~m}$ operating range of the crane were selected for $\mathrm{CO}_{2}$ enrichment (three Fagus sylvatica, three Quercus petraea, three Carpinus betulus, one Tilia platyphyllos, one Acer campestre, one Prunus avium) and received elevated atmospheric $\mathrm{CO}_{2}$ since autumn 2000. In 2006, the individual Prunus avium tree suffered from storm damage and was therefore excluded from the $\mathrm{CO}_{2}$ enrichment. An adequate number of control trees were accessible in the remaining crane area at sufficient distance to the $\mathrm{CO}_{2}$-enriched zone.

\section{Leaf gas exchange measurements}

In early July and mid-September of 2008, instantaneous rates of $\mathrm{CO}_{2} / \mathrm{H}_{2} \mathrm{O}$ gas exchange were measured with two identical portable photosynthesis systems (LI-6400, LI-COR Biosciences, Lincoln, NE, USA) on 25 trees of five species. Light-saturated net photosynthetic rates (PPFD = 1,200 $\mu \mathrm{mol} \mathrm{m}{ }^{-2} \mathrm{~s}^{-1}$, LI-COR 6400-02 LED light unit) were determined between 8:30 and 12:30 h at ambient and elevated $\mathrm{CO}_{2}$ concentrations (i.e. at 380 and $550 \mathrm{ppm}$ ) at $25^{\circ} \mathrm{C}$ leaf temperature and air-to-leaf vapour pressure deficit (ALVPD) of $1.18 \pm 0.01$ and $1.47 \pm 0.02 \mathrm{kPa}$ (means $\pm \mathrm{SE}$ ) in June and September, respectively. Measurements were taken on eight mature leaves per tree from different sunlit branches. Leaves that initially showed low stomatal conductance $<70 \mathrm{mmol} \mathrm{m}^{-2}$ $\mathrm{s}^{-1}$ were replaced by leaves exceeding this threshold. By means of the adjustable leaf chamber $\mathrm{CO}_{2}$ supply, gas exchange was first measured at $380 \mathrm{ppm} \mathrm{CO}_{2}$ and subsequently, on the same leaf, at $550 \mathrm{ppm} \mathrm{CO}_{2}$, designated hereafter as $A_{380}$ and $A_{550}$, respectively. The light-saturated net photosynthesis measured at growth $\mathrm{CO}_{2}$ concentration is termed $A_{\text {growth }}$. Recordings were taken as soon as the net rate of photosynthesis and stomatal conductance $\left(g_{\mathrm{s}}\right)$ remained constant. Individual measurements did not exceed $5 \mathrm{~min}$. The instantaneous photosynthetic enhancement ratio $\left(E^{\prime}\right)$ was calculated as the leaf-intrinsic ratio of $A_{550} / A_{380}$ for any tree in ambient and elevated $\mathrm{CO}_{2}$. The enhancement ratio that compares $A_{\text {growth }}$ of $\mathrm{CO}_{2}$-enriched trees ( $\left.A_{\text {growth }}^{\mathrm{e}}\right)$ with $A_{\text {growth }}$ of control trees growing under ambient conditions ( $A_{\text {growth }}^{\text {a }}$ ) is denoted by $E$. We calculated $E$ using weighted species means to account for the varying number of trees available in each species (less weight assigned to Acer and Tilia that occurred with only one tree individual in each $\mathrm{CO}_{2}$ treatment). Both photosynthetic enhancement ratios, $E^{\prime}$ and $E$, were 
expressed as percentages $\left(A_{550} / A_{380}\right.$ or $A_{\text {growth }}^{\mathrm{e}} / A_{\text {growth }}^{\mathrm{a}}-$ $1 \times 100 \%)$. In addition, $A / C_{\mathrm{i}}$ curves of the replicated species ( $F$. sylvatica, $Q$. petraea, $C$. betulus) were recorded on two to four leaves per tree. Gas exchange rates were first recorded at a leaf chamber $\mathrm{CO}_{2}$ concentration $\left(C_{\mathrm{a}}\right)$ of 400 ppm $\mathrm{CO}_{2}$, before $C_{\mathrm{a}}$ was stepwise reduced to 300,200 , 100 and $40 \mathrm{ppm}$, subsequently $C_{\mathrm{a}}$ was returned to $400 \mathrm{ppm}$ (to check if the initial rate could be restored) and then increased to $600,800,1,000,1,500$ and 2,000 ppm. Individual response curves were completed within 25-35 min. $A / C_{\mathrm{i}}$ curves were analysed using a Farquhar-type photosynthesis model (Long and Bernacchi 2003). Nonlinear least squares regression was applied to estimate $V_{\text {cmax }}$, the maximal carboxylation rate of ribulose 1,5-bisphosphate carboxylase/oxygenase (Rubisco), $J_{\max }$, the maximal rate of electron transport, and photosynthetic limitation due to triose-phosphate utilisation (TPU-limitation).

\section{Leaf properties}

At peak season (July 2008), we also measured leaf thickness (SM 112, Teclock, Nagano, Japan, precision $0.01 \mathrm{~mm}$ ) and foliar chlorophyll content non-destructively (CCM-200, Opti-Sciences, Tyngsboro, MA, USA) on 30 leaves per tree canopy. A different set of ten leaf samples per tree was collected with a leaf puncher for determination of SLA, leaf $\mathrm{N}$ and NSC concentrations. Immediately after sampling, leaf discs $\left(1.2 \mathrm{~cm}^{2}\right)$ were dried at $80^{\circ} \mathrm{C}$ for at least $48 \mathrm{~h}$ and then weighed for biomass quantification. Then, samples were ground and all samples from one tree were pooled for determination of leaf $\mathrm{N}$ concentration ( $\mathrm{mg} \mathrm{N} \mathrm{g}^{-1}$ dry mass) using a CHN-analyzer (Vario EL III, Elementar Analysensysteme GmbH, Hanau, Germany). Non-structural carbohydrates (NSC $=$ starch, sucrose, glucose and fructose) were analysed applying an enzymatic starch digestion followed by a spectrophotometric glucose test after invertase and isomerase addition (Körner and Miglietta 1994).

Statistical analysis

Gas exchange parameters were analysed using a linear mixed-effects model. We fitted the model using restricted maximum likelihood (REML) and included the fixed factors 'species', 'FACE-treatment' and 'leaf chamber $\mathrm{CO}_{2}$ '. 'Leaf chamber $\mathrm{CO}_{2}$ ' was also nested within the random factor 'tree individual'. The photosynthetic enhancement ratios $E$ and $E^{\prime}$ were analysed in three-way repeated measures ANOVAs with the fixed factors 'FACE-treatment', 'species' and 'date'. $\mathrm{CO}_{2}$ effects on leaf properties were analysed with two-way ANOVAs with the fixed factors 'species' and 'FACE-treatment'. All statistical analyses and graphics were performed using R version 2.9.0 (http://www.r-project.org).

\section{Results}

\section{Leaf gas exchange}

In the early and late growing season during year 8 of $\mathrm{CO}_{2}$ enrichment, the instantaneous enhancement of light-saturated net photosynthesis by elevated $\mathrm{CO}_{2}\left(E^{\prime}=A_{550} / A_{380}\right)$ was similar in trees growing under ambient and elevated
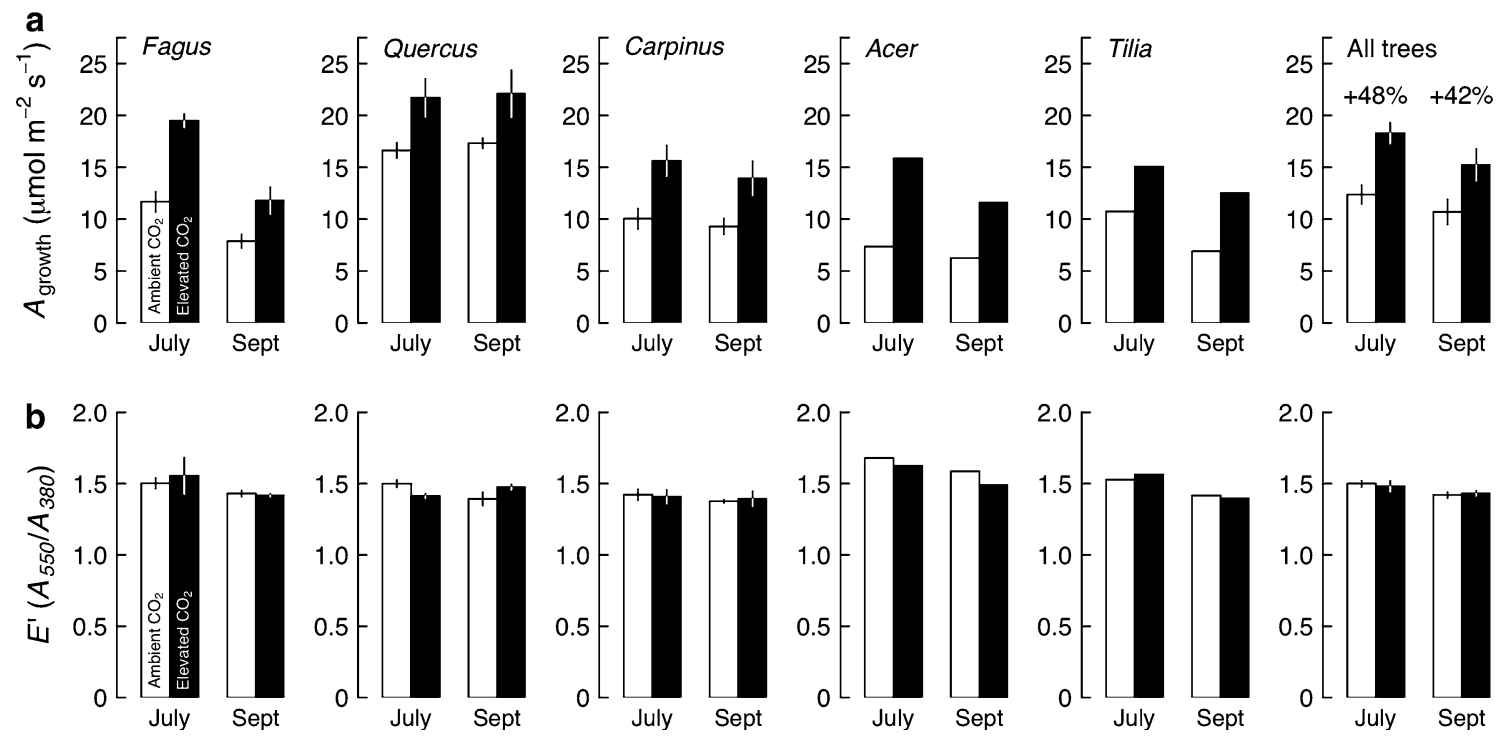

Fig. $1 \mathrm{CO}_{2}$-induced enhancement of light-saturated leaf photosynthesis of five deciduous tree species measured in the mid and late growing season of 2008 at the SCC FACE site, Switzerland. Trees were growing in a near-natural stand under ambient (white) or elevated $\mathrm{CO}_{2}$ (black). a Light-saturated net photosynthesis measured at growth $\mathrm{CO}_{2}$ concentration, $A_{\text {growth }}$. b Instantaneous leaf-intrinsic photosynthetic enhancement, $E^{\prime}=A_{550} / A_{380}$. Means $\pm \mathrm{SE}, n=11$ (elevated $\left.\mathrm{CO}_{2}\right), n=14\left(\right.$ ambient $\mathrm{CO}_{2}$ ) 
Table 1 Results of a three-way ANOVA on the effects of species identity, FACE and sampling date (peak and late growing season) on the instantaneous leaf-intrinsic photosynthetic enhancement $\left(E^{\prime}\right)$ involved with a switch in leaf chamber $\mathrm{CO}_{2}$ from 380 to $550 \mathrm{ppm}$

\begin{tabular}{lllc}
\hline Factor & $D f$ & $F$ & $P$ \\
\hline Species & 4,15 & 4.380 & $<0.010^{* *}$ \\
FACE & 1,15 & 0.005 & 0.947 \\
Date & 1,15 & 8.030 & $<0.010^{* *}$ \\
Species $\times$ FACE & 4,15 & 0.177 & 0.948 \\
Species $\times$ date & 4,15 & 0.535 & 0.710 \\
FACE $\times$ date & 1,15 & 0.603 & 0.444 \\
Species $\times$ FACE $\times$ date & 4,15 & 1.032 & 0.407
\end{tabular}

$D f$ degrees of freedom (numerator, denominator); $F F$-value

$* * P<0.01$

Table 2 Linear mixed-effects model results on the effects of species identity, FACE and leaf chamber $\mathrm{CO}_{2}$ on photosynthetic capacity of five deciduous tree species growing under ambient and elevated $\mathrm{CO}_{2}$ $\left(\mathrm{FACE}=\mathrm{CO}_{2}\right.$ effect, $\mathrm{CO}_{2}$ - $\mathrm{LC}=$ leaf chamber $\mathrm{CO}_{2}$ concentration $)$

\begin{tabular}{llrc}
\hline Factor & $D f$ & \multicolumn{1}{l}{$P$} \\
\hline Species & 4,15 & 17.838 & $<0.001^{* * *}$ \\
Date & 1,781 & 190.947 & $<0.001^{* * *}$ \\
FACE & 1,15 & 0.008 & 0.929 \\
$\mathrm{CO}_{2}$-LC & 1,19 & 1045.290 & $<0.001^{* * *}$ \\
Species $\times$ FACE & 4,15 & 0.833 & 0.525 \\
Species $\times$ date & 4,781 & 44.540 & $<0.001^{* * *}$ \\
Species $\times \mathrm{CO}_{2}$-LC & 4,19 & 1.281 & 0.312 \\
FACE $\times \mathrm{CO}_{2}$-LC & 1,19 & 0.047 & 0.830 \\
FACE $\times \mathrm{date}_{\text {Date }} \times \mathrm{CO}_{2}$-LC & 1,781 & 0.398 & 0.528 \\
Species $\times$ FACE $\times$ date & 1,781 & 5.421 & $0.020^{*}$ \\
\end{tabular}

$D f$ degrees of freedom (numerator, denominator); $F F$-value

*** $P<0.001, * * P<0.01, * P<0.05$

$\mathrm{CO}_{2}$ (Fig. 1; Table 1). Averaged across all trees, the shortterm switch in $\mathrm{CO}_{2}$ supply to the leaf chamber from 380 to $550 \mathrm{ppm}$ led to a photosynthetic enhancement of $49 \%$ in early July and declined significantly to $42 \%$ in September (Fig. 1; Table 2). As a consequence of this strong $\mathrm{CO}_{2}$ stimulation, the rate of light-saturated net photosynthesis measured at growth $\mathrm{CO}_{2}$ concentration $\left(A_{\text {growth }}\right)$ was significantly higher in $\mathrm{CO}_{2}$-enriched trees compared to ambient controls ( $\left.E=A_{\text {growth }}^{\mathrm{e}} / A_{\text {growth }}^{\mathrm{a}}\right)$ reaching $48 \%$ in July and $42 \%$ in September (Fig. 1). There was significant variation amongst the study species with Quercus petraea showing the highest rates of net photosynthesis under both treatments and at both measured leaf chamber $\mathrm{CO}_{2}$ levels, whilst the lowest rates were seen in Acer campestre (Table 2). The significance of the species $\times$ FACE $\times$ date interaction (indicating species-specific down-regulation over the growing season, Table 2) was caused by the single Tilia tree and when this

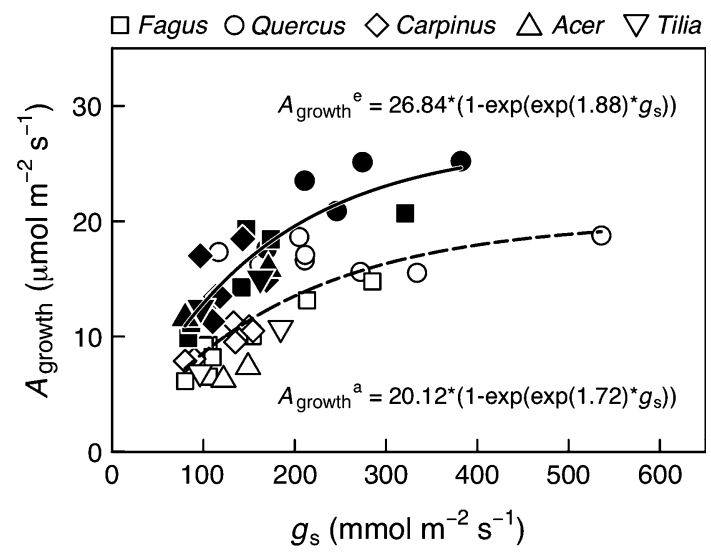

Fig. 2 Net photosynthesis under growth $\mathrm{CO}_{2}$ concentration $\left(A_{\text {growth }}\right)$ as a function of stomatal conductance $\left(g_{\mathrm{s}}\right)$ in ambient (white) and $\mathrm{CO}_{2}$-enriched foliage (black) of five mature deciduous tree species, measured in the peak and late growing season of 2008. Means \pm SE, $n=1-5$ per species and treatment

unreplicated species was disregarded in the model the interaction term lost its significance. From the early to the late growing season, the average $A_{\text {growth }}$ declined significantly by $15-17 \%$ under ambient ( 12.4 vs. $10.7 \mu \mathrm{mol} \mathrm{m} \mathrm{m}^{-2}$ $\mathrm{s}^{-1}$ ) and elevated $\mathrm{CO}_{2}$ (18.3 vs. $15.2 \mu \mathrm{mol} \mathrm{m}{ }^{-2} \mathrm{~s}^{-1}$, threeway ANOVA, $P<0.001)$. Stomatal conductance declined towards the end of the growing season by 41 and $33 \%$ in ambient and elevated $\mathrm{CO}_{2}$ (three-way ANOVA, $P<0.001$ ). Comparing foliage grown and measured under ambient $\mathrm{CO}_{2}$ with foliage grown and measured under elevated $\mathrm{CO}_{2}$ yielded similar stomatal conductance $\left(g_{\mathrm{s}}\right)$, but 6 and $9 \%$ lower transpiration rates in July and September, respectively. However, these differences in transpiration were statistically not significant (three-way repeated measures ANOVA, $P>0.2$ ). Rates of $A_{\text {growth }}$ and $g_{\text {s }}$ were tightly coupled, and $A_{\text {growth }}^{\mathrm{e}}$ was always higher than $A_{\text {growth }}^{\mathrm{a}}$ at a common $g_{\mathrm{s}}$ (Fig. 2). Since leaf $\mathrm{N}$ in $\mathrm{CO}_{2}$-enriched trees was not reduced (see later), photosynthetic net carbon uptake per unit leaf nitrogen (nitrogen-use efficiency, PNUE) was significantly higher compared to control trees (Table 4).

The carboxylation efficiency of Rubisco $\left(V_{\mathrm{cmax}}\right)$ and the maximal rate of electron transport leading to RubP regeneration $\left(J_{\max }\right)$ showed significant inter-specific variation, but $\mathrm{CO}_{2}$ enrichment as main effect had no significant influence. The significant species $\times$ FACE $\times$ date interaction for $V_{\text {cmax }}$ resulted mainly from increases in $V_{\text {cmax }}$ in Quercus control trees towards the end of the growing season, rather than from a late-seasonal down-regulation in $\mathrm{CO}_{2}$-enriched trees. In a number of leaves, $A / C_{\mathrm{i}}$ curves also showed that photosynthesis became limited by triosephosphate utilisation $\left(5.3-12.6 \mu \mathrm{mol} \mathrm{m}^{-2} \mathrm{~s}^{-1}\right)$ when $C_{\mathrm{i}}$ exceeded $\sim 750 \mathrm{ppm}$.

Across species and treatments, $V_{\text {cmax }}$ and $J_{\max }$ had significantly declined by 11 and $8 \%$ over the growing season 
Fig. 3 The seasonal response of light-saturated net photosynthesis $\left(A_{\text {net }}\right)$ to intercellular $\mathrm{CO}_{2}$ concentration $\left(C_{\mathrm{i}}\right)$ in upper-canopy leaves of mature individuals of the three dominant deciduous tree species growing under ambient (white, dashed lines) and elevated $\mathrm{CO}_{2}$ (black, solid lines) in a nearnatural stand at the SCC FACE site, Switzerland. The bar chart inserts give the maximum rate of Rubisco carboxylation $\left(V_{\text {cmax }}\right)$, the maximum electron transport rate $\left(J_{\max }\right)$ and the $J_{\text {max }} / V_{\text {cmax }}$ ratio derived from a Farquhar-type photosynthesis model. The response curves shown in the graph were fitted using nonlinear least squares regression based on the equation used by Herrick and Thomas (2001): $A=A_{\max }[1-(1-\alpha /$ $\left.\left.A_{\max }\right)\left(1-C_{\mathrm{i}} / \Gamma\right)\right]$, where $A_{\max }=A_{\text {net }}$ at $\mathrm{CO}_{2}$ saturation, $\alpha=y$-intercept and $\Gamma=\mathrm{CO}_{2}$ compensation point. Means \pm SE, $n=3-5$ per species and treatment

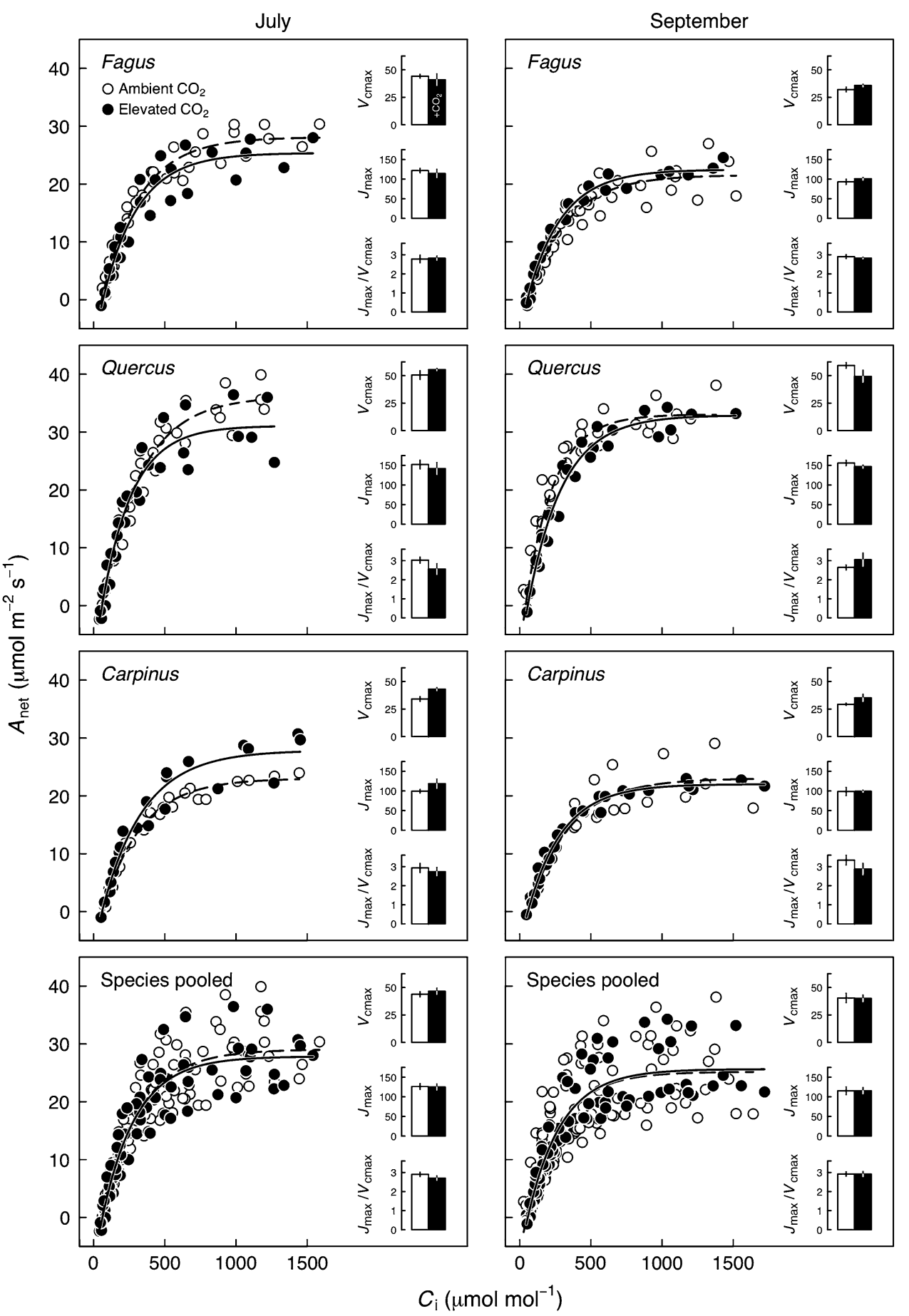

(Fig. 3; Table 3). We observed a common positive linear relationship between $J_{\max }$ and $V_{\text {cmax }}$, which was similar in leaves grown under ambient and elevated $\mathrm{CO}_{2}$ and did not change with progressing growing season ( $F$ test, $F=0.232, P=0.963$, Fig. 4). Neither $V_{\text {cmax }}$ nor $J_{\max }$ was significantly correlated with leaf $\mathrm{N}$ on an area basis ( $\mathrm{N} \mathrm{m}^{-2}$, data not shown).

\section{Leaf traits}

In year 8 of the FACE study, all measured leaf traits showed significant inter-specific variation, but $\mathrm{CO}_{2}$ enrichment as main effect had no significant influence (Table 4). However, across all trees, $\mathrm{CO}_{2}$ exposure tended to increase leaf non-structural carbohydrates (NSC, 
Table 3 Results of a three-way ANOVA on the effects of species identity, FACE and sampling date (peak and late growing season) on the maximum rate of Rubisco carboxylation ( $\left.V_{\mathrm{cmax}}\right)$, maximum electron transport rate $\left(J_{\max }\right)$ and the ratio $J_{\max } / V_{\text {cmax }}$ in the three replicated tree species (Fagus sylvatica, Quercus petraea, Carpinus betulus)

\begin{tabular}{|c|c|c|c|}
\hline Factor & $D f$ & $F$ & $P$ \\
\hline \multicolumn{4}{|l|}{$V_{\text {cmax }}$} \\
\hline Species & 2,16 & 45.976 & $<0.001 * * *$ \\
\hline FACE & 1,16 & 0.712 & 0.405 \\
\hline Date & 1,15 & 7.889 & $0.009 * *$ \\
\hline Species $\times$ FACE & 2,16 & 2.792 & 0.078 \\
\hline Species $\times$ date & 2,15 & 4.712 & $0.016^{*}$ \\
\hline FACE $\times$ date & 1,15 & 1.012 & 0.322 \\
\hline Species $\times$ FACE $\times$ date & 2,15 & 3.606 & $0.039 *$ \\
\hline \multicolumn{4}{|l|}{$J_{\max }$} \\
\hline Species & 2,16 & 37.534 & $<0.001 * * *$ \\
\hline FACE & 1,16 & 0.003 & 0.954 \\
\hline Date & 1,15 & 4.570 & $0.041 *$ \\
\hline Species $\times$ FACE & 2,16 & 1.272 & 0.295 \\
\hline Species $\times$ date & 2,15 & 2.888 & 0.071 \\
\hline FACE $\times$ date & 1,15 & 0.003 & 0.961 \\
\hline Species $\times$ FACE $\times$ date & 2,15 & 0.977 & 0.388 \\
\hline \multicolumn{4}{|l|}{$J_{\max } / V_{\text {cmax }}$} \\
\hline Species & 2,16 & 0.606 & 0.552 \\
\hline FACE & 1,16 & 0.948 & 0.338 \\
\hline Date & 1,15 & 0.788 & 0.382 \\
\hline Species $\times$ FACE & 2,16 & 0.693 & 0.508 \\
\hline Species $\times$ date & 2,15 & 0.464 & 0.633 \\
\hline FACE $\times$ date & 1,15 & 0.527 & 0.474 \\
\hline Species $\times$ FACE $\times$ date & 2,15 & 2.294 & 0.118 \\
\hline
\end{tabular}

$D f$ degrees of freedom (numerator, denominator); $F F$-value

*** $P<0.001, * * P<0.01, * P<0.05$

$+15 \%$ ), which was largely driven by Quercus that showed $36 \%$ increase in leaf NSC under elevated $\mathrm{CO}_{2}$ (Table 4). There was also a trend towards a decline in specific leaf area (SLA) under elevated $\mathrm{CO}_{2}$, which disappeared when the two unreplicated species were excluded from the statistical analysis or when SLA was expressed on an NSCfree basis (Table 4). We found species-dependent $\mathrm{CO}_{2}$ effects on leaf chlorophyll content and leaf $\mathrm{N}$ (significant species $\times$ treatment interaction). $\mathrm{CO}_{2}$-enriched Quercus trees showed $20 \%$ less foliar chlorophyll than conspecific control trees, whilst Fagus leaves exhibited ca. 30\% higher chlorophyll contents under elevated $\mathrm{CO}_{2}$. The significant species $\times$ treatment interaction with leaf $\mathrm{N}$ (on an area basis) resulted solely from the decline seen in Acer (-28\%) and Tilia $(-14 \%)$. When these two unreplicated species were excluded from the analysis, the interaction term lost significance (Table 4).

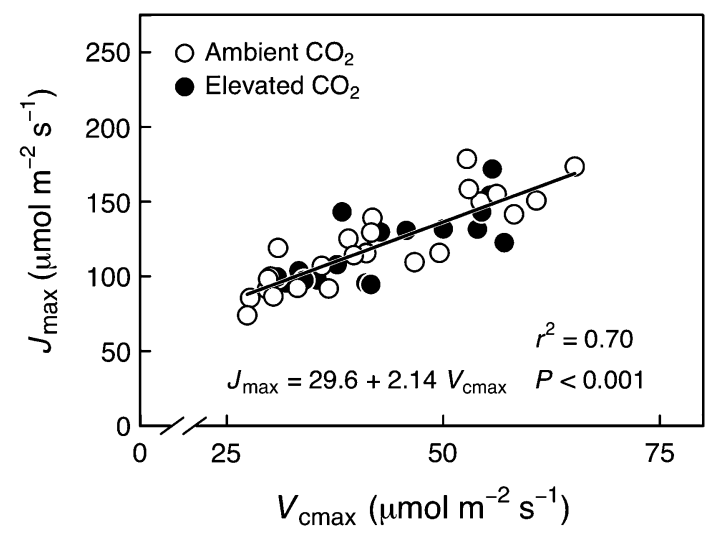

Fig. 4 Correlation between the maximum rate of electron transport $\left(J_{\max }\right)$ driving RubP regeneration and the maximum rate of Rubisco carboxylation $\left(V_{\text {cmax }}\right)$ of mature leaves in the outer canopy of the three dominant deciduous tree species at the SCC site [Fagus sylvatica, Quercus petraea, and Carpinus betulus, means $\pm \mathrm{SE}$, $n=9$ (elevated $\left.\mathrm{CO}_{2}\right), n=12$ (ambient $\left.\left.\mathrm{CO}_{2}\right)\right]$. Treatment- and datewise regression was statistically not different from the regression analysis applied to the combined data from ambient and elevated $\mathrm{CO}_{2}$ in July and September; therefore the pooled data set is shown

\section{Discussion}

\section{Leaf gas exchange}

The Swiss Canopy Crane gave us the unique possibility to reveal the long-term effects of $\mathrm{CO}_{2}$ enrichment on photosynthesis in mature, 30-35 m tall deciduous forest trees. In the canopy of the mixed forest stand at the SCC site, net photosynthetic rates of sunlit foliage from mature trees that had been grown under future atmospheric $\mathrm{CO}_{2}$ for 8 years were consistently higher compared with rates in leaves of control trees $(E=48 \%$ in July and $42 \%$ in September, Fig. 1). In the same stand, Zotz et al. (2005) found 36 and $49 \%$ photosynthetic enhancement $(E)$ in the mid and late growing season, respectively, after 3 years of $\mathrm{CO}_{2}$ enrichment ( $E$ given here is corrected for the loss of one $\mathrm{CO}_{2}$-exposed tree in 2006 and was recalculated with the original data using weighted species means). Thus, the magnitude of photosynthetic enhancement at the SCC forest did not change over the study years and agrees well with the numbers reported from other multi-year FACE experiments performed with trees (Herrick and Thomas 2001, Liquidambar styraciflua in the understory at Duke-FACE: +63\%; Sholtis et al. 2004, L. styraciflua at ORNL-FACE: +44\%; Liberloo et al. 2007, three Populus species at POP-FACE: $+49 \%$; Ainsworth and Rogers 2007, review: $+46 \%$ in trees, Crous et al. 2008, Pinus taeda at Duke-FACE: $+68 \%$ in current year needles, $+40 \%$ in 1-year-old needles). At the Aspen-FACE site, Populus tremuloides clones initially showed somewhat lower stimulation especially under $\mathrm{CO}_{2}+\mathrm{O}_{3}$ conditions 


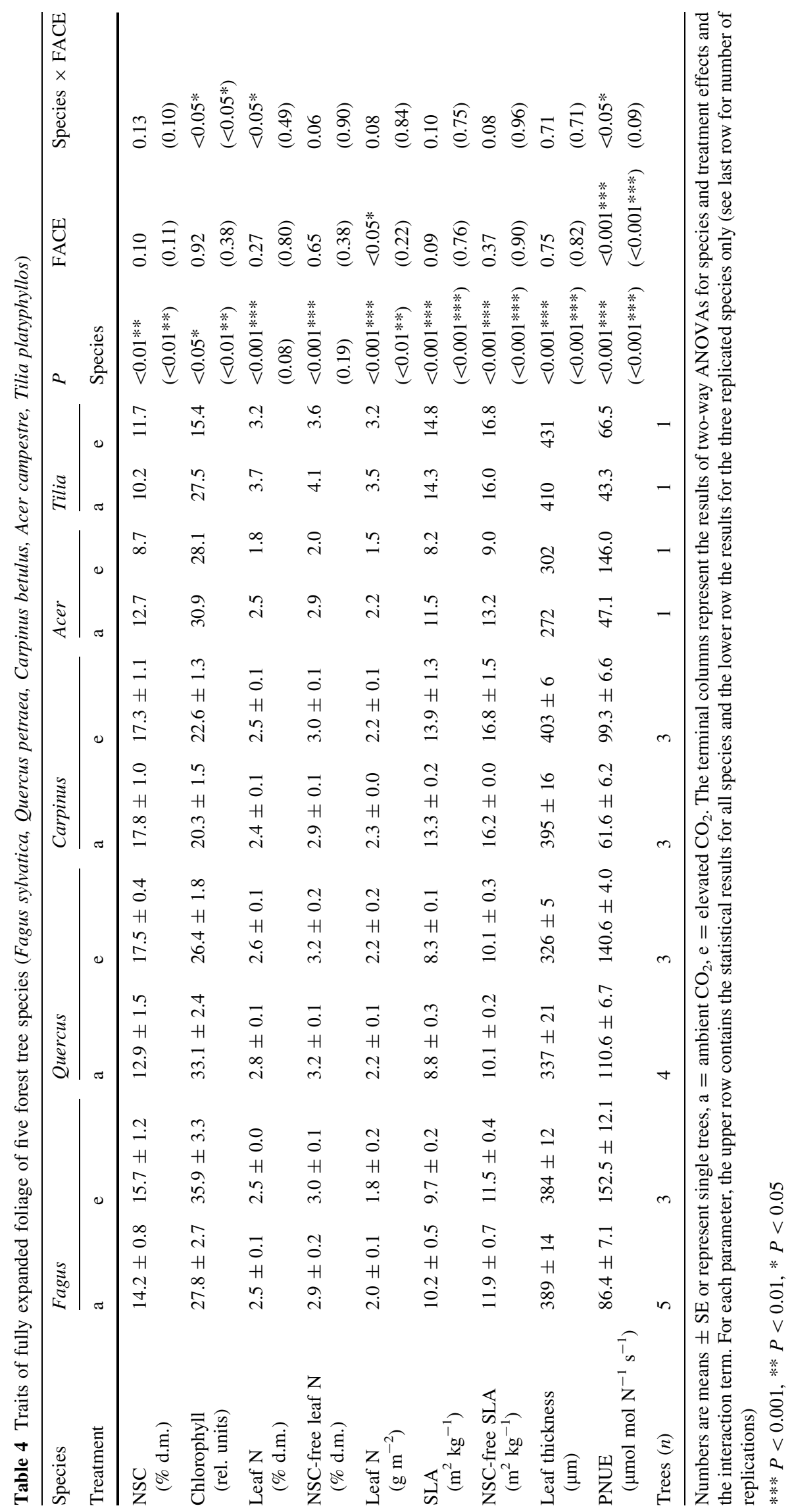


(Noormets et al. 2001). However, when LAI had reached steady-state, photosynthetic capacity in $\mathrm{CO}_{2}$-enriched Populus clones and Betula papyfera trees was increased by 76 and $115 \%$, respectively, and the addition of $\mathrm{O}_{3}$ (elevated $\mathrm{CO}_{2}+\mathrm{O}_{3}$ treatment) did not significantly reduce the $\mathrm{CO}_{2}$ driven stimulation in photosynthesis (Uddling et al. 2009).

Although previous measurements revealed reduced sapflow in our $\mathrm{CO}_{2}$-enriched trees (Cech et al. 2003; Leuzinger and Körner 2007), we did not measure reduced $g_{\text {s }}$ under elevated $\mathrm{CO}_{2}$. However, the relationship between $A_{\text {growth }}$ and $g_{\text {s }}$ suggests improved water-use-efficiency (Fig. 2). A similar relationship between $A_{\text {growth }}$ and $g_{\mathrm{s}}$ was reported for Liquidambar styraciflua trees at the ORNLFACE site, which, in contrast to our trees, showed a significant $24 \%$ decline in $g_{\mathrm{s}}$ under elevated $\mathrm{CO}_{2}$ (Gunderson et al. 2002).

In their meta-analysis of photosynthetic responses to elevated $\mathrm{CO}_{2}$ in FACE experiments, Ainsworth and Rogers (2007) reported moderate but significant decreases in $V_{\text {cmax }}$ $(-6 \%)$ in trees growing under high $\mathrm{CO}_{2}$. At our site, trees receiving $\mathrm{CO}_{2}$ enrichment did not show reduced $V_{\text {cmax }}$ not even towards the end of the growing season when downregulation due to declining sink strength is most commonly observed. Downward adjustment of $J_{\max }$ in response to elevated $\mathrm{CO}_{2}$ has less often been reported (Long et al. 2004; Ainsworth and Long 2005) and was not apparent in our $\mathrm{CO}_{2}$-enriched trees.

The lack of photosynthetic down-regulation is consistent with the findings for mature and understory sweetgum trees growing at the ORNL- and Duke-FACE site, respectively, and three poplar species growing at short-rotation coppice at the POP-FACE site as well as for aspen and birch at the ASPEN-FACE stands (Herrick and Thomas 2001; Sholtis et al. 2004; Liberloo et al. 2007; Uddling et al. 2009).

Down-regulation of photosynthesis in response to $\mathrm{CO}_{2}$ enrichment is often associated with a decline in leaf $\mathrm{N}$ (Stitt 1991; Medlyn et al. 1999) and thus occurs more often under limited soil N availability (Oren et al. 2001). Although the steady-state pine forest at the DUKE-FACE facility is such an $\mathrm{N}$-limited system, long-term exposure to elevated $\mathrm{CO}_{2}$ did not affect needle $\mathrm{N}$ irrespective of needle age. Nonetheless, $V_{\text {cmax }}$ and $J_{\max }$ declined significantly and reduced photosynthetic enhancement by $37 \%$ in 1-year-old needles of $\mathrm{CO}_{2}$-enriched Pinus taeda trees (Rogers and Ellsworth 2002; Crous et al. 2008). These declines resulted from NSC accumulation that caused strong selective downregulation of Rubisco (Rogers and Ellsworth 2002). In current-year needles that showed no down-regulation, the photosynthetic enhancement by elevated $\mathrm{CO}_{2}$ was therefore substantially higher compared to 1-year-old needles (68 vs. 40\%; Crous et al. 2008). Interestingly, N-fertilisation in the last FACE year restored photosynthetic capacity in 1-year-old needles suggesting that $\mathrm{CO}_{2}$ enrichment reduced the allocation of $\mathrm{N}$ to Rubisco and RuBP regeneration and to proteins associated with electron transport in 1-year-old needles. The authors concluded that curtailing the $\mathrm{N}$ supply to photosynthesis could make more $\mathrm{N}$ available for new foliage growth at low fertility sites (Crous et al. 2008). However, even in well-fertilised sour orange trees, photosynthesis was gradually down-regulated during 14 years of growth in elevated $\mathrm{CO}_{2}$ (Adam et al. 2004).

The SCC stand grows in an area with ample precipitation and high wet nitrogen deposition (20-25 $\mathrm{kg} \mathrm{N}^{-1} \mathrm{a}^{-1}$ ) and is thus believed to be free of N-limitation. Consequently, we assumed strong initial growth stimulation by elevated $\mathrm{CO}_{2}$ that would only start to acclimatise a few years after the FACE initiation (Körner 2006). However, apart from transient growth stimulation in Fagus during the early years of the experiment, we did not observe any consistent, significant increases in growth or biomass or the acceleration of turnover processes above or below ground under elevated $\mathrm{CO}_{2}$ (Körner et al. 2005; Asshoff et al. 2006; Keel et al. 2006; Bader et al. 2009). Although stable isotope data and soil air $\mathrm{CO}_{2}$ concentration both indicated an increased flux of $\mathrm{C}$ into the soil (Keel et al. 2006), we did not detect a corresponding signal in soil respiration that could account for the fate of the extra $\mathrm{C}$ assimilated under elevated $\mathrm{CO}_{2}$ (Bader and Körner 2010). The lack of strong sink capacity for assimilates led us to assume considerable down-regulation of photosynthesis in trees receiving $\mathrm{CO}_{2}$ enrichment. Instead, we found persistent stimulation of photosynthesis implying a lack of closure in the $\mathrm{C}$ budget, clearly pointing to so far unaccounted $\mathrm{C}$ fluxes in this $\mathrm{CO}_{2}$ enrichment experiment. Preliminary findings indicate that parts of the extra $\mathrm{C}$ assimilated under elevated $\mathrm{CO}_{2}$ may leave the system through enhanced leaching of dissolved organic and inorganic C $(<20 \%$, F. Hagedorn, personnel communication).

\section{Leaf traits}

Similar to previous years, the overall trend towards increased leaf NSC under elevated $\mathrm{CO}_{2}$ resulted mainly from the strong buildup seen in Quercus leaves (Table 4; Körner et al. 2005). As discussed earlier, NSC accumulation in leaves may lead to photosynthetic down-regulation, but photosynthesis $\left(A_{\text {growth }}\right.$ and $\left.E^{\prime}\right)$ in Quercus foliage remained unaffected by the $\mathrm{CO}_{2}$-induced increase in NSC. Similarly strong accumulation of leaf NSC $(+37 \%)$ was observed in Liquidambar styraciflua (sweetgum) leaves at the ORNLFACE site and there the sugar signal also failed to downregulate photosynthesis (Sholtis et al. 2004). Consistent with the lack of photosynthetic down-regulation, leaf $\mathrm{N}$ assessed at peak season was not affected by $\mathrm{CO}_{2}$ enrichment, except for the single Acer tree that showed a large decrease in leaf $\mathrm{N}$. This contrasts with the findings from the early years of the 
experiment that showed an overall reduction of $10 \%$ in leaf $\mathrm{N}$ driven by a pronounced decline in Carpinus and the dilution by NSC (Körner et al. 2005). A $10 \%$ reduction in leaf $\mathrm{N}$ (mass based) was also reported for sweetgum trees at the ORNL stands (Sholtis et al. 2004), whilst needle N in Pinus taeda growing on low fertile soil at the Duke-FACE forest and leaf $\mathrm{N}$ in deciduous trees at the POP- and AspenFACE stands remained unaffected by $\mathrm{CO}_{2}$ exposure (Liberloo et al. 2007; Crous et al. 2008; Uddling et al. 2009).

The changes in area-based chlorophyll content observed in Fagus and Quercus were not linked to changes in SLA and had no effect on $V_{\text {cmax }}$ or $J_{\max }$. Commonly, foliar chlorophyll content is little affected under FACE conditions (Long et al. 2004; Ainsworth and Long 2005), and declines on a mass basis observed in sweetgum trees (ORNL-FACE) were fully explained by reductions in SLA (ca. $-10 \%$, Sholtis et al. 2004). During the first 4 years of the SCC experiment, elevated $\mathrm{CO}_{2}$ diminished SLA by 5-8\% in all species but Fagus (Körner et al. 2005), whereas in year 8 only Acer showed lower SLA under elevated $\mathrm{CO}_{2}$. Also, Pinus taeda growing at the Duke forest showed no SLA response to elevated $\mathrm{CO}_{2}$ (Rogers and Ellsworth 2002), but SLA declined up to $24 \%$ in the upper canopy of a poplar coppice exposed to elevated $\mathrm{CO}_{2}$ (POP-FACE, Liberloo et al. 2007). In general, leaf traits of our study trees were surprisingly little affected by $\mathrm{CO}_{2}$ enrichment.

Even if the $\mathrm{CO}_{2}$-induced decline in SLA observed during the early years of the experiment disappeared over time, it did not preclude changes in leaf production. However, at our site, annual leaf litter production and thus LAI remained unchanged under elevated $\mathrm{CO}_{2}$ (Körner et al. 2005 and later unpublished data), which was consistent with earlier studies reporting the lack of an LAI response to $\mathrm{CO}_{2}$ enrichment in closed canopy stands (Hättenschwiler et al. 1997; Gielen et al. 2003; Norby et al. 2003). Steady-state LAI had, however, increased in pure aspen and mixed aspen birch stands growing under elevated $\mathrm{CO}_{2}$ at the Aspen-FACE site (Uddling et al. 2008).

\section{Conclusions}

Photosynthetic enhancement (42-48\%) in mature trees of five broad-leaved species was sustained without reductions over 8 years of canopy $\mathrm{CO}_{2}$ enrichment. Provided that future climatic trends will not strongly affect photosynthesis directly and nutrient availability will remain sufficient, these findings suggest that the enhancement of photosynthesis may persist in these mature deciduous trees under high future atmospheric $\mathrm{CO}_{2}$ concentrations. The fate of the additional $\mathrm{C}$ assimilated by $\mathrm{CO}_{2}$-exposed trees growing in this closed canopy forest remains uncertain. Above- and below-ground growth responses to elevated
$\mathrm{CO}_{2}$ were inconsistent suggesting that the extra $\mathrm{C}$ was not used to build up significantly more biomass in these old trees.

Acknowledgments We thank Erwin Amstutz for crane operations and for his efforts in data collection. We are grateful to the Paul Scherrer Institute (Switzerland) for the provision of equipment. Further, we thank Olivier Bignucolo for various laboratory analyses of leaf parameters. The SCC FACE study was supported by the Swiss National Science Foundation (grant 3100AO-111914/1).

\section{References}

Adam NR, Wall GW, Kimball BA, Idso SB, Webber AN (2004) Photosynthetic down-regulation over long-term $\mathrm{CO}_{2}$ enrichment in leaves of sour orange (Citrus aurantium) trees. New Phytol 163:341-347

Ainsworth EA, Long SP (2005) What have we learned from 15 years of free-air $\mathrm{CO}_{2}$ enrichment (FACE)? A meta-analytic review of the responses of photosynthesis, canopy properties and plant production to rising $\mathrm{CO}_{2}$. New Phytol 165:351-371

Ainsworth EA, Rogers A (2007) The response of photosynthesis and stomatal conductance to rising $\mathrm{CO}_{2}$ : mechanisms and environmental interactions. Plant Cell Environ 30:258-270

Asshoff R, Zotz G, Körner C (2006) Growth and phenology of mature temperate forest trees in elevated $\mathrm{CO}_{2}$. Glob Change Biol 12:848-861

Bader M, Körner C (2010) No overall stimulation of soil respiration under mature deciduous forest trees after 7 years of $\mathrm{CO}_{2}$ enrichment. Glob Change Biol. doi:10.1111/j.1365-2486.2010. 02159.x (in press)

Bader M, Hiltbrunner E, Körner C (2009) Fine root responses of mature deciduous forest trees to free air carbon dioxide enrichment (FACE). Funct Ecol 23:913-921

Bonan GB (2008) Forests and climate change: forcings, feedbacks, and the climate benefits of forests. Science 320:1444-1449

Cech PG, Pepin S, Körner C (2003) Elevated $\mathrm{CO}_{2}$ reduces sap flux in mature deciduous forest trees. Oecologia 137:258-268

Crous KY, Walters MB, Ellsworth DS (2008) Elevated $\mathrm{CO}_{2}$ concentration affects leaf photosynthesis-nitrogen relationships in Pinus taeda over nine years in FACE. Tree Physiol 28:607-614

Curtis PS, Wang XZ (1998) A meta-analysis of elevated $\mathrm{CO}_{2}$ effects on woody plant mass, form, and physiology. Oecologia 113: 299-313

Drake BG, Gonzalez-Meler MA, Long SP (1997) More efficient plants: a consequence of rising atmospheric $\mathrm{CO}_{2}$ ? Annu Rev Plant Physiol Plant Mol Biol 48:609-639

Egli P, Maurer S, Spinnler D, Landolt W, Gunthardt-Georg MS, Körner C (2001) Downward adjustment of carbon fluxes at the biochemical, leaf, and ecosystem scale in beech-spruce model communities exposed to long-term atmospheric $\mathrm{CO}_{2}$ enrichment. Oikos 92:279-290

Ellsworth DS, Reich PB, Naumburg ES, Koch GW, Kubiske ME, Smith SD (2004) Photosynthesis, carboxylation and leaf nitrogen responses of 16 species to elevated $p \mathrm{CO}_{2}$ across four free-air $\mathrm{CO}_{2}$ enrichment experiments in forest, grassland and desert. Glob Change Biol 10:2121-2138

Farquhar GD, von Caemmerer S, Berry JA (1980) A biochemical model of photosynthetic $\mathrm{CO}_{2}$ assimilation in leaves of $\mathrm{C}_{3}$ species. Planta 149:78-90

Gielen B, Liberloo M, Bogaert J, Calfapietra C, De Angelis P, Miglietta F, Scarascia-Mugnozza G, Ceulemans R (2003) Three years of free-air $\mathrm{CO}_{2}$ enrichment (POPFACE) only slightly 
affect profiles of light and leaf characteristics in closed canopies of Populus. Glob Change Biol 9:1022-1037

Gunderson CA, Wullschleger SD (1994) Photosynthetic acclimation in trees to rising atmospheric $\mathrm{CO}_{2}-\mathrm{a}$ broader perspective. Photosynth Res 39:369-388

Gunderson CA, Sholtis JD, Wullschleger SD, Tissue DT, Hanson PJ, Norby RJ (2002) Environmental and stomatal control of photosynthetic enhancement in the canopy of a sweetgum (Liquidambar styraciflua L.) plantation during 3 years of $\mathrm{CO}_{2}$ enrichment. Plant Cell Environ 25:379-393

Hättenschwiler S, Miglietta F, Raschi A, Körner C (1997) Thirty years of in situ tree growth under elevated $\mathrm{CO}_{2}$ : a model for future forest responses? Glob Change Biol 3:463-471

Herrick JD, Thomas RB (2001) No photosynthetic down-regulation in sweetgum trees (Liquidambar styraciflua $\mathrm{L}$.) after three years of $\mathrm{CO}_{2}$ enrichment at the Duke forest FACE experiment. Plant Cell Environ 24:53-64

Keel SG, Siegwolf RTW, Körner C (2006) Canopy $\mathrm{CO}_{2}$ enrichment permits tracing the fate of recently assimilated carbon in a mature deciduous forest. New Phytol 172:319-329

Körner C (2006) Plant $\mathrm{CO}_{2}$ responses: an issue of definition, time and resource supply. New Phytol 172:393-411

Körner C, Miglietta F (1994) Long-term effects of naturally elevated $\mathrm{CO}_{2}$ on mediterranean grassland and forest trees. Oecologia 99:343-351

Körner C, Asshoff R, Bignucolo O, Hättenschwiler S, Keel SG, Pelaez-Riedl S, Pepin S, Siegwolf RTW, Zotz G (2005) Carbon flux and growth in mature deciduous forest trees exposed to elevated $\mathrm{CO}_{2}$. Science 309:1360-1362

Le Quéré C, Raupach MR, Canadell JG, Marland G, Bopp L, Ciais P, Conway TJ, Doney SC, Feely RA, Foster P, Friedlingstein P, Gurney K, Houghton RA, House JI, Huntingford C, Levy PE, Lomas MR, Majkut J, Metzl N, Ometto JP, Peters GP, Prentice IC, Randerson JT, Running SW, Sarmiento JL, Schuster U, Sitch S, Takahashi T, Viovy N, van der Werf GR, Woodward FI (2009) Trends in the sources and sinks of carbon dioxide. Nat Geosci 2:421-436

Leuzinger S, Körner C (2007) Water savings in mature deciduous forest trees under elevated $\mathrm{CO}_{2}$. Glob Change Biol 13:24982508

Liberloo M, Tulva I, Raim O, Kull O, Ceulemans R (2007) Photosynthetic stimulation under long-term $\mathrm{CO}_{2}$ enrichment and fertilization is sustained across a closed Populus canopy profile (EUROFACE). New Phytol 173:537-549

Long SP, Bernacchi CJ (2003) Gas exchange measurements, what can they tell us about the underlying limitations to photosynthesis? Procedures and sources of error. J Exp Bot 54:2393-2401

Long SP, Ainsworth EA, Rogers A, Ort DR (2004) Rising atmospheric carbon dioxide: plants face the future. Annu Rev Plant Biol 55:591-628

Medlyn BE, Badeck FW, De Pury DGG, Barton CVM, Broadmeadow M, Ceulemans R, De Angelis P, Forstreuter M, Jach ME, Kellomaki S, Laitat E, Marek M, Philippot S, Rey A, Strassemeyer J, Laitinen K, Liozon R, Portier B, Roberntz P, Wang K, Jarvis PG (1999) Effects of elevated $\mathrm{CO}_{2}$ on photosynthesis in European forest species: a meta-analysis of model parameters. Plant Cell Environ 22:1475-1495

Moore BD, Cheng SH, Sims D, Seemann JR (1999) The biochemical and molecular basis for photosynthetic acclimation to elevated atmospheric $\mathrm{CO}_{2}$. Plant Cell Environ 22:567-582
Noormets A, McDonald EP, Dickson RE, Kruger EL, Sober A, Isebrands JG, Karnosky DF (2001) The effect of elevated carbon dioxide and ozone on leaf- and branch-level photosynthesis and potential plant-level carbon gain in aspen. Trees Struct Funct $15: 262-270$

Norby RJ, Wullschleger SD, Gunderson CA, Johnson DW, Ceulemans $\mathrm{R}$ (1999) Tree responses to rising $\mathrm{CO}_{2}$ in field experiments: implications for the future forest. Plant Cell Environ 22:683-714

Norby RJ, Sholtis JD, Gunderson CA, Jawdy SS (2003) Leaf dynamics of a deciduous forest canopy: no response to elevated $\mathrm{CO}_{2}$. Oecologia 136:574-584

Nowak RS, Ellsworth DS, Smith SD (2004) Functional responses of plants to elevated atmospheric $\mathrm{CO}_{2}$-do photosynthetic and productivity data from FACE experiments support early predictions? New Phytol 162:253-280

Oren R, Ellsworth DS, Johnsen KH, Phillips N, Ewers BE, Maier C, Schäfer KVR, McCarthy H, Hendrey G, Mcnulty SG, Katul GG (2001) Soil fertility limits carbon sequestration by forest ecosystems in a $\mathrm{CO}_{2}$-enriched atmosphere. Nature 411:469-472

Pepin S, Körner C (2002) Web-FACE: a new canopy free-air $\mathrm{CO}_{2}$ enrichment system for tall trees in mature forests. Oecologia 133:1-9

Rogers A, Ellsworth DS (2002) Photosynthetic acclimation of Pinus taeda (loblolly pine) to long-term growth in elevated $p \mathrm{CO}_{2}$ (FACE). Plant Cell Environ 25:851-858

Roy J, Saugier B, Mooney HA (2001) Terrestrial global productivity. Academic Press, San Diego

Sabine CL, Heimann M, Artaxo P, Bakker DCE, Chen C-TA, Field CB, Gruber N, Le Quéré C, Prinn RG, Richey JE, Lankao PR, Sathaye JA, Valentini R (2004) Current status and past trends of the global carbon cycle. In: Field CB, Raupach MR (eds) Global carbon cycle-integrating humans climate and the natural world. Island Press, Washington, DC, pp 17-44

Saxe H, Ellsworth DS, Heath J (1998) Tree and forest functioning in an enriched $\mathrm{CO}_{2}$ atmosphere. New Phytol 139:395-436

Schimel DS (1995) Terrestrial ecosystems and the carbon cycle. Glob Change Biol 1:77-91

Sholtis JD, Gunderson CA, Norby RJ, Tissue DT (2004) Persistent stimulation of photosynthesis by elevated $\mathrm{CO}_{2}$ in a sweetgum (Liquidambar styraciflua) forest stand. New Phytol 162:343-354

Stitt M (1991) Rising $\mathrm{CO}_{2}$ level and their potential significance for cabon flow in photosynthetic cells. Plant Cell Environ 14:741-762

Stitt M, Krapp A (1999) The interaction between elevated carbon dioxide and nitrogen nutrition: the physiological and molecular background. Plant Cell Environ 22:583-621

Tans P (2008) Trends in atmospheric carbon dioxide. Web page NOAA/ESRL http://www.esrl.noaa.gov/gmd/ccgg/trends/. Accessed 27 July 2009

Uddling J, Teclaw RM, Kubiske ME, Pregitzer KS, Ellsworth DS (2008) Sap flux in pure aspen and mixed aspen-birch forests exposed to elevated concentrations of carbon dioxide and ozone. Tree Physiol 28:1231-1243

Uddling J, Teclaw RM, Pregitzer KS, Ellsworth DS (2009) Leaf and canopy conductance in aspen and aspen-birch forests under free-air enrichment of carbon dioxide and ozone. Tree Physiol 29:1367-1380

Zotz G, Pepin S, Körner C (2005) No down-regulation of leaf photosynthesis in mature forest trees after three years of exposure to elevated $\mathrm{CO}_{2}$. Plant Biol 7:369-374 